\title{
Maximum potential for geothermal power in Germany based on engineered geothermal systems
}

\author{
Charitra Jain ${ }^{1,2^{*}}$, Christian Vogt ${ }^{1,3}$ and Christoph Clauser ${ }^{1}$
}

\author{
${ }^{*}$ Correspondence: \\ charitra.jain@erdw.ethz.ch \\ ${ }^{1}$ Institute for Applied Geophysics \\ and Geothermal Energy, E.ON \\ Energy Research Center, RWTH \\ Aachen University, Mathieustr. 10, \\ 52074 Aachen, Germany \\ 2 Institute of Geophysics, \\ Department of Earth Sciences, ETH \\ Zürich, Sonneggstrasse 5, 8092 \\ Zürich, Switzerland \\ Full list of author information is \\ available at the end of the article
}

\begin{abstract}
We estimate the maximum geothermal potential in Germany available for exploitation by operated engineered geothermal systems (EGS). To this end, we assume that (a) capabilities for creating sufficient permeability in engineered deep heat exchange systems will become available in the future and (b) it will become possible to implement multiple wells in the reservoir for extending the rock volume accessible by water circulation for increasing the heat yield. While these assumptions may be challenged as far too optimistic, they allow for testing the potential of EGS, given the required properties, in countries lacking natural steam reservoirs. With this aim, we model numerically the thermal and electric energies which may be delivered by such systems by solving coupled partial differential equations governing fluid flow and heat transport in a porous medium. Thus, our model does not represent the engineered fractures in their proper physical dimension but rather distributes their flow volume in a small region of enhanced permeability around them. By varying parameters in the subsurface, such as flow rates and well separations, we analyze the long-term performance of this engineered reservoir. For estimating the maximum achievable potential for EGS in Germany, we assume the most optimistic conditions, realizing that these are unlikely to prevail. Considering the available crystalline landmass and accounting for the competing land uses, we evaluate the overall EGS potential and compare it with that of other renewables used in Germany. Under most optimistic assumptions, the land surface available for emplacing EGS would support a maximum of 13,450 EGS plants each comprising 18 wells and delivering an average electric power of $35.3 \mathrm{MW}_{\mathrm{e}}$. When operated at full capacity, these systems collectively may supply 4155 TWh of electric energy in 1 year which would be roughly seven times the electric energy produced in Germany in the year 2011. Thus, our study suggests that major scientific, engineering, and financial efforts are justified for developing the drilling and stimulation technologies required for creating the permeabilities required for successful EGS. Then, EGS will have great potential for contributing towards national power production in a future powered by sustainable, decentralized energy systems.
\end{abstract}

Keywords: EGS; Geothermal; Optimization; Potential; Renewable

\section{包 Springer}

(c) 2015 Jain et al. Open Access This article is distributed under the terms of the Creative Commons Attribution 4.0 International License (http://creativecommons.org/licenses/by/4.0), which permits unrestricted use, distribution, and reproduction in any medium, provided you give appropriate credit to the original author(s) and the source, provide a link to the Creative Commons license, and indicate if changes were made. The Creative Commons Public Domain Dedication waiver (http://creativecommons. org/publicdomain/zero/1.0/) applies to the data made available in this article, unless otherwise stated. 


\section{Background}

Geothermal energy is renewable, environmentally friendly, and ubiquitous. Yet, only a tiny fraction of it is harnessed commercially for space heating or for electricity by conversion at some expense (Clauser 2006). The grade of all geothermal resources depends on the temperature difference between produced and re-injected water, the fluid flow rate and hence, reservoir rock permeability and porosity, and the amount of fluid saturation (Tester et al. 2006). For exploiting high-grade resources, it is desirable to access deeper parts of the Earth's crust as rock temperature increases with depth. At the same time, decreasing rock permeability and exponentially increasing drilling costs with depth (Heidinger 2010) can render a geothermal installation uneconomical.

In the presence of natural steam or hot water reservoirs, electricity can be produced by forcing high-pressure steam or organic vapor to drive the turbines. In their absence and when the reservoirs lack sufficient permeability for effective heat transfer, engineered geothermal systems (EGS) may be employed for electricity production by engineering the reservoir (Clauser 2006). They cogenerate heat and power and can be used for large-scale applications like district heating or base-load power supply with capacity factors above $90 \%$ (Bertani 2009). But the process of heat extraction from the subsurface using EGS needs optimization.

In this paper, we study the long-term response of operated EGS reservoirs based on numerical stimulation (Clauser 2003) of an optimized heat extraction process. We systematically vary parameters such as flow rate and well separation in the subsurface and study various EGS configurations and their sustainability. Additionally, based on the available land area and competing land uses in Germany, the maximum national EGS potential is evaluated and compared with potentials of already used renewables like solar energy, wind, and biomass.

Reservoirs with insufficient fracture network or hydraulic permeability may be stimulated by hydraulic fracturing by which critically stressed rocks either fail, dilate along pre-existing shear zones or faults, or the permeability of existing fractures is enhanced as high-pressure fluids are injected into the subsurface rocks via injection wells (Clauser 2006). In a perfect continuum, the direction of the fracture opening and propagation depends on the existing stress regimes. When the difference between maximum compressive stress $\sigma_{1}$ and minimum compressive stress $\sigma_{3}$ is large, fractures open and propagate in a direction which is parallel to $\sigma_{3}$ and $\sigma_{1}$, respectively (Pettitt et al. 2011). In real rock, pre-existing, healed fractures or fracture networks accumulated in its tectonic history will be activated and enhanced.

In a simple EGS layout, two or three wells are drilled into the subsurface reservoir reaching depths of up to $5 \mathrm{~km}$ terminating several hundred meters apart. Water is circulated from the injection (injector) to the production (producer) wells through a system of open, connected fractures where it becomes heated by contact with the rock. Hot water produced at the surface is used for generating electricity, usually in a binary plant with possible subsequent use of the unconverted remaining heat for room heating and cooling. These systems may be either open or closed.

Several EGS case studies worldwide have demonstrated the principle feasibility of heat extraction from stimulated and engineered reservoirs although all fell short regarding the projected flow rate and power. The pioneering work in the field of EGS was the Hot Dry Rock (HDR) project at Fenton Hill (New Mexico, USA) where the reservoir was formed 
by opening pre-existing, but sealed, multiply-connected joint sets (Brown and Duchane 1999). At Rosemanowes (Cornwall, UK), the reservoir was engineered to have a large network of micro-cracks, fissures, and fractures but only a limited number of major fractures turned out to account for most of the flow (Kolditz and Clauser 1998; Parker 1999). The EGS project at Soultz-sous-Forêts, France, has a system of interconnected faults and large-scale fractures (Baria et al. 1999; Breesee 2015). Contrary to the two previous sites, the Soultz EGS plant is the only one to be exploited. See Gérard et al. (2006) and Kohl and Schmittbuhl $(2014,2015)$ for a recent overview regarding Soultz-sous-Forêts and deep geothermal systems in general. All three configurations are illustrated in Fig. 1.

\section{Methods}

\section{Numerical modeling}

The finite-difference method is used for solving the transient coupled equations of fluid flow and heat transfer in a fluid-saturated porous medium as implemented in the forward modeling code SHEMAT (Clauser 2003). Thus, we assume that macroscopically, i.e., with respect to flow on the scale of our finite-difference discretization, the fractured zone may be approximated by a porous medium.

\section{Governing equations}

The partial differential equations governing the fluid flow and heat transport are derived from conservation of mass, momentum, and energy. Momentum conservation is expressed by Darcy's law which describes the groundwater flow in a confined aquifer as:

$$
\boldsymbol{v}=-\frac{\underline{k}}{\mu_{f}}\left(\nabla P+\rho_{f} \cdot g \cdot \nabla z\right)
$$

where $\boldsymbol{v}$ is specific discharge (or Darcy velocity) $\left(\mathrm{m} \mathrm{s}^{-1}\right), \underline{k}$ is hydraulic permeability tensor $\left(\mathrm{m}^{2}\right), \mu_{f}$ is fluid dynamic viscosity (Pa s), $P$ is hydraulic pressure $(\mathrm{Pa}), \rho_{f}$ is fluid density

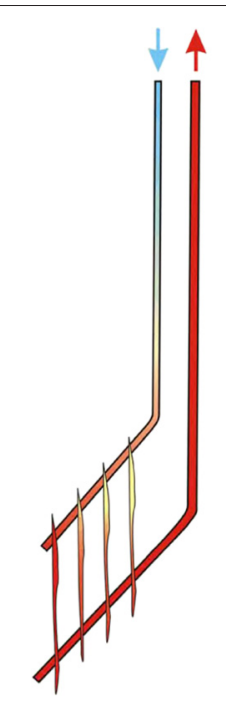

(a) coin-shaped vertical cracks

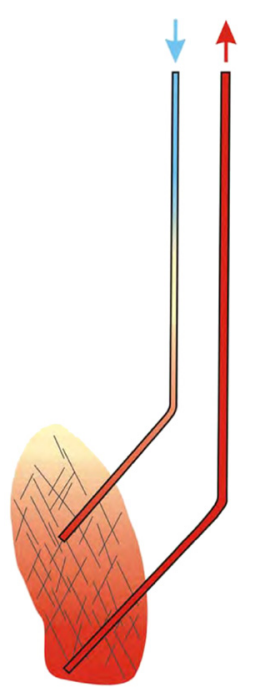

(b) network of micro-cracks, fissures and fractures

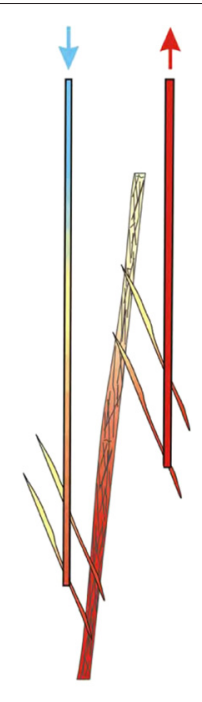

(c) interconnected largescale fractures and faults

Fig. 1 Fracture and subsurface heat exchanger configurations for EGS. a Fenton Hill (New Mexico, USA), b Rosemanowes (Cornwall, UK), and c Soultz-sous-Forêts (France) (Clauser 2006) 
$\left(\mathrm{kg} \mathrm{m}^{-3}\right), g$ is gravity $\left(\mathrm{m} \mathrm{s}^{-2}\right)$, and $z$ is depth $(\mathrm{m})$ (where $z$ is pointing vertically upward) (Clauser 2003). The equivalent hydraulic head $h_{0}(\mathrm{~m})$ and measured hydraulic head $h(\mathrm{~m})$ are given as:

$$
\begin{aligned}
& h_{0}=\frac{P}{\rho_{0} \cdot g}+z_{d} \\
& h=\frac{h_{0} \cdot \rho_{0}}{\rho_{f}}
\end{aligned}
$$

where $\rho_{0}$ is the reference density $\left(998 \mathrm{~kg} \mathrm{~m}^{-3}\right)$ and $\rho_{f}$ is the fluid density that is constant over depth (862 $\mathrm{kg} \mathrm{m}^{-3}$ ) (Kühn et al. 2002).

Corresponding pore water pressure is calculated by distribution of equivalent hydraulic head $h_{0}$ (Eq.2) and depth $z_{d}$ as:

$$
P\left(z_{d}, h_{0}\right)=P_{0}+\int_{0}^{z_{d}} \rho_{f}\left(z_{d}\right) \cdot g \cdot\left(h_{0}-z_{d}\right) \cdot d z_{d}
$$

where $P_{0}\left(z_{0}\right) \approx 10^{5} \mathrm{~Pa}$ is the pressure at the surface $z_{d}=0$ (Vogt et al. 2012).

The continuity equation expresses the conservation of mass as:

$$
0=\partial\left(\phi \cdot \rho_{f}\right) / \partial t+\nabla \cdot\left(\rho_{f} \cdot \boldsymbol{v}\right)
$$

where $\phi$ is porosity (Clauser 2003).

The equation for fluid flow is derived from Eqs. 1, 4, and 5 using the OberbeckBoussinesq approximation (Boussinesq 1903; Oberbeck 1879):

$$
\rho_{f} \cdot g \cdot(\alpha+\phi \cdot \beta) \frac{\partial h}{\partial t}=\nabla \cdot\left[\frac{\rho_{f} \cdot g \cdot \underline{k}}{\mu_{f}}\left(\nabla h_{0}+\rho_{r} \cdot \nabla z\right)\right]+W
$$

where $\alpha$ and $\beta$ are the compressibility $\left(\mathrm{Pa}^{-1}\right)$ of the rock and the fluid phase, respectively. $W$ denotes the mass source term $\left(\mathrm{kg} \mathrm{m}^{-3} \mathrm{~s}^{-1}\right)$ (Vogt et al. 2012).

The heat transport equation is obtained by conservation of energy (Clauser 2003):

$$
(\rho \cdot c)_{e} \frac{\partial T}{\partial t}=\nabla \cdot\left(\underline{\lambda_{e}} \cdot \nabla T-(\rho \cdot c)_{f} \cdot T \cdot \mathbf{v}\right)+H
$$

where $(\rho \cdot c)_{e}$ is the effective volumetric heat capacity of the saturated porous medium and the fluid $\left(\mathrm{J} \mathrm{m}^{-3} \mathrm{~K}^{-1}\right), T$ is temperature $\left({ }^{\circ} \mathrm{C}\right),(\rho \cdot c)_{f}$ is fluid volumetric heat capacity $\left(\mathrm{J} \mathrm{m}^{-3} \mathrm{~K}^{-1}\right), \underline{\lambda_{e}}$ is the tensor of effective thermal conductivity $\left(\mathrm{W} \mathrm{m}^{-1} \mathrm{~K}^{-1}\right)$, and $H$ the heat generation rate source term $\left(\mathrm{W} \mathrm{m}^{-3}\right)$.

There is a non-linear coupling between Eqs. 6 and 7. Flow depends on heat transport via the temperature dependence of the fluid viscosity and compressibility. Heat transport depends on flow via heat advection, the pressure dependence of fluid thermal conductivity, and fluid volumetric thermal capacity. Apart from the constant fluid density, other fluid properties are calculated and updated simultaneously during the numerical simulations. Transfer of heat takes place by advection and conduction in the porous medium neglecting the contribution of thermal dissipation, radiation, and dispersion (Clauser 2003).

\section{Model geometry and properties}

The technical details concerning whether and, if so, how a sufficiently permeable heat exchange system may be engineered at depth, are currently under debate. Clearly, previous attempts fell short of fully providing the anticipated flow rates and, hence, thermal 
and electric power. In the past decades, great progress was achieved in drilling and stimulation technology enabling operations previously considered impossible. Therefore, it is not unreasonable to assume, for the purpose of this paper, that in the coming one to two decades, developments in drilling and stimulation technology will overcome the current shortcomings. Based on this assumption, this paper evaluates the ramifications of these technologies regarding the conversion of deep geothermal heat into electric energy. The technicalities of engineering permeability at depth, however, are beyond the scope of this study. Our purpose here is not simulating the fluid mechanics of fracture flow but rather the thermal effect of a focused volume flow on heat transport. Considering that it is possible to encounter some major fractures in the subsurface (as in Soultz-sous-Forêts), we assume in our study coin-shaped fractures as a simplification for an EGS reservoir. The modeling problem is addressed by an equivalent porous medium approach where instead of simulating one small discrete fracture, a wider zone of increased permeability (zone 5) is simulated representing the fracture (not resolved individually) as well as the damaged zone around it. The permeability of this fractured zone is chosen such that the resulting volumetric flow rate is the same as for a single planar fracture.

Economides and Nolte (2003) state that the fracture apertures lie in the range of 3-10 $\mathrm{mm}$ for low-to-medium permeability formations. Simulating zone 5 by a width of $5 \mathrm{~mm}$ with high porosity of $95 \%$ resulted in numerical instability. Therefore, we consider a box-shaped fractured zone (zone 5) with a width of $1 \mathrm{~m}$, a permeability of $10^{-11} \mathrm{~m}^{2}$ and a porosity of $0.5 \%$ which is embedded in the surrounding zone (zone 4). In principle, assuming such a high permeability may be questioned as unrealistic. This has certainly been true until today. But again, we are not discussing whether or how fractures of this permeability can be engineered but are interested rather in what would be the resulting geothermal potential if this were to become possible in the future.

Zones 4-5 have higher porosity and permeability values than zones 1-3 to allow for the fluid circulation. These zones should be large enough to provide enough volume for fluid circulation; otherwise, the injected fluids will follow a direct shorter path to the producer without heating up properly. This simple configuration of engineered fractures can be easily extrapolated and is thereby not limited to a particular EGS project. Properties assigned for the different zones are given in Table 1 (see also Fig. 2).

The reservoir volume is represented by a numerical grid (Fig. 3) comprising $35 \times 85 \times$ 121 cells. The cell dimensions vary from 1 to 160,10 to 200 , and 20 to $160 \mathrm{~m}$ in $x$-, $y$-, and $z$-directions, respectively ( $z$ positive upward). The grid is refined near the injectors and the producers to accommodate for the higher fluid velocities at these locations. This grid

Table 1 Spatial, hydraulic, and thermal properties of the different zones of the model

\begin{tabular}{llllll}
\hline Parameter & Zone 1 & Zone 2 & Zone 3 & Zone 4 & Zone 5 \\
\hline Width in $x$-direction $(\mathrm{m})$ & 1271 & 1271 & 1271 & 311 & 1 \\
Length in $y$-direction $(\mathrm{m})$ & 4620 & 4620 & 4620 & 4420 & 4220 \\
Thickness in z-direction $(\mathrm{m})$ & 400 & 2300 & 400 & 2300 & 2020 \\
Porosity & 0.001 & 0.001 & 0.001 & 0.002 & 0.005 \\
Permeability $\left(\mathrm{m}^{2}\right)$ & $10^{-18}$ & $10^{-19}$ & $10^{-20}$ & $10^{-15}$ & $10^{-11}$ \\
Rock compressibility $\left(\mathrm{Pa}^{-1}\right)$ & $10^{-10}$ & $10^{-10}$ & $10^{-10}$ & $10^{-10}$ & $10^{-10}$ \\
Thermal capacity $\left(\mathrm{MJ} \mathrm{m}^{-3} \mathrm{~K}^{-1}\right)$ & 2.1 & 2.1 & 2.1 & 2.1 & 2.1 \\
Thermal conductivity $\left(\mathrm{W} \mathrm{m}^{-1} \mathrm{~K}^{-1}\right)$ & 2.7 & 2.7 & 2.7 & 2.7 & 2.7 \\
\hline
\end{tabular}




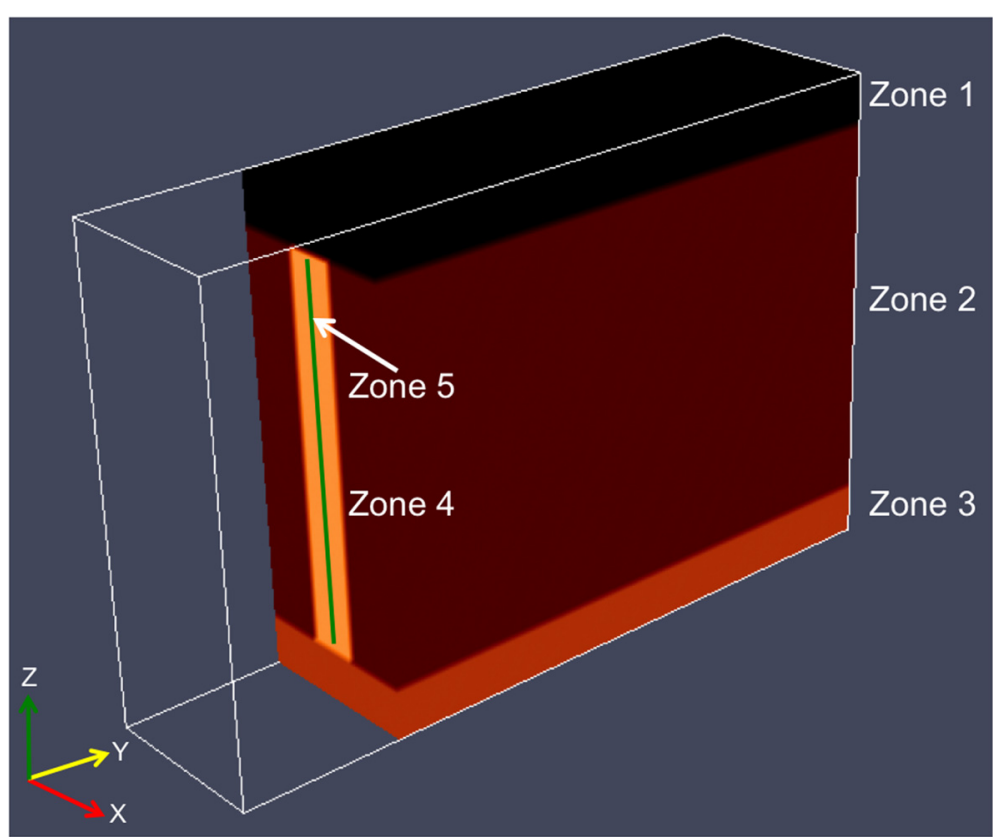

Fig. 2 Property zones defined in the model. Fractured zone (zone 5) is shown in green (not to scale)

discretization represents a trade-off between the conflicting goals of achieving reasonable computing times (with a coarser grid) and preventing loss of relevant details (with a finer grid) while maintaining numerical stability (Fig. 3). The model consists of five property zones (Fig. 2) with zones 1-3 extending over the entire length and width of the reservoir volume. Oriented vertically, as in the case of vertical maximum compressive stress in a homogeneous medium, the 311-m thick zone 4 (surrounding zone) lies within zone 2. The zone of engineered increased permeability is realized in the model as described and justified in "Background" section. The low-porosity crystalline (granite) reservoir is

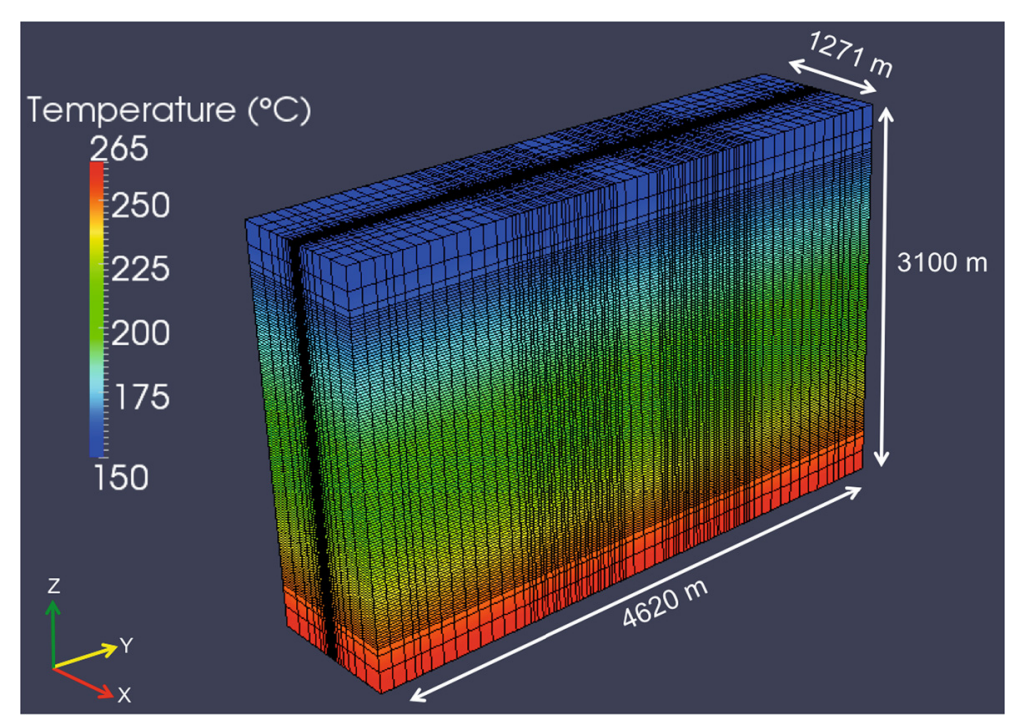

Fig. 3 Numerical grid and undisturbed temperature field defined for the reservoir volume 
considered at a depth range of $4000-7100 \mathrm{~m}$ with a temperature of $150{ }^{\circ} \mathrm{C}$ at the top. A basal specific heat flow of $0.08 \mathrm{~W} \mathrm{~m}^{-2}$ marks the lower boundary condition of the reservoir, both values reflecting conditions as, for instance, in the southern Upper Rhine Graben in France or Germany.

\section{Simulation and results}

An undisturbed temperature field over the reservoir volume is obtained by running a steady-state simulation which is then used as input for the transient coupled heat and fluid flow simulation. A doublet is introduced with the injector and the producer placed $1200 \mathrm{~m}$ apart in the fracture zone at depths of $5550 \mathrm{~m}$ (model depth of $1550 \mathrm{~m}$ ) and $5350 \mathrm{~m}$ (model depth of $1350 \mathrm{~m}$ ), respectively. Water is injected at a temperature of $80^{\circ} \mathrm{C}$ with a constant flow rate of $50 \mathrm{~L} \mathrm{~s}^{-1}\left(0.05 \mathrm{~m}^{3} \mathrm{~s}^{-1}\right)$ at the injector and produced at higher temperatures with the same flow rate (assuming $100 \%$ water recovery from the reservoir) from the producer. The total simulation time is divided into six stress periods (Table 2), summing up to 31.58 years (11,527 days). Simulations are carried out on 12 Intel $^{\circ} \mathrm{Xeon}^{\circ} \mathrm{X} 5690$ $3.47 \mathrm{GHz}$ processors. As our simulator allows only an input of volume (rather than mass) flow rates at the injectors and producers, the density of injected water is set to a constant value of $862 \mathrm{~kg} \mathrm{~m}^{-3}$ (at temperature $=200{ }^{\circ} \mathrm{C}$ and salinity $=0 \mathrm{mg} \mathrm{L}^{-1}$ (NOAA 2012)). If the water density is not kept constant, it varies by around $15 \%$ over the simulation time with varying temperature. As this density variation causes a mass difference between the water injected and produced at different temperatures, hydraulic head will increase continuously. Therefore, this mass difference is avoided in the simulations by fixing water density at a constant value.

The development of bottom-hole temperature at the producer and the engineered high-permeability heat-exchange area in the fractured zone is shown in Figs. 4 and 5, respectively. Temperatures decrease uniformly with time as the reservoir is cooled by the heat extraction. A slight temperature increase at the beginning ( $\sim$ first 200 days) is due to the fact that the producer is located $200 \mathrm{~m}$ above the injector. Thus, it produces colder water before warmer water reaches there. The continuous injection and production of water result in a pressure increase at the injector and a pressure decrease at the producer over time.

\section{Results and discussion \\ Optimization}

Before the model from subsection "Simulation and results" is adapted to accommodate a triplet (1 injector, 2 producers) or a reversed-triplet ( 2 injectors, 1 producer) or modular layouts, it needs to be optimized for producing the highest possible electric energy over an EGS's assumed operational life span of 31 years. A comprehensive study follows where two

Table 2 Time parameters for the transient simulation

\begin{tabular}{lll}
\hline Stress period & Duration (years) & Number of time steps \\
\hline 1 & 0.0834 & 20 \\
2 & 0.5 & 20 \\
3 & 1 & 20 \\
4 & 5 & 20 \\
5 & 10 & 20 \\
6 & 15 & 20 \\
\hline
\end{tabular}




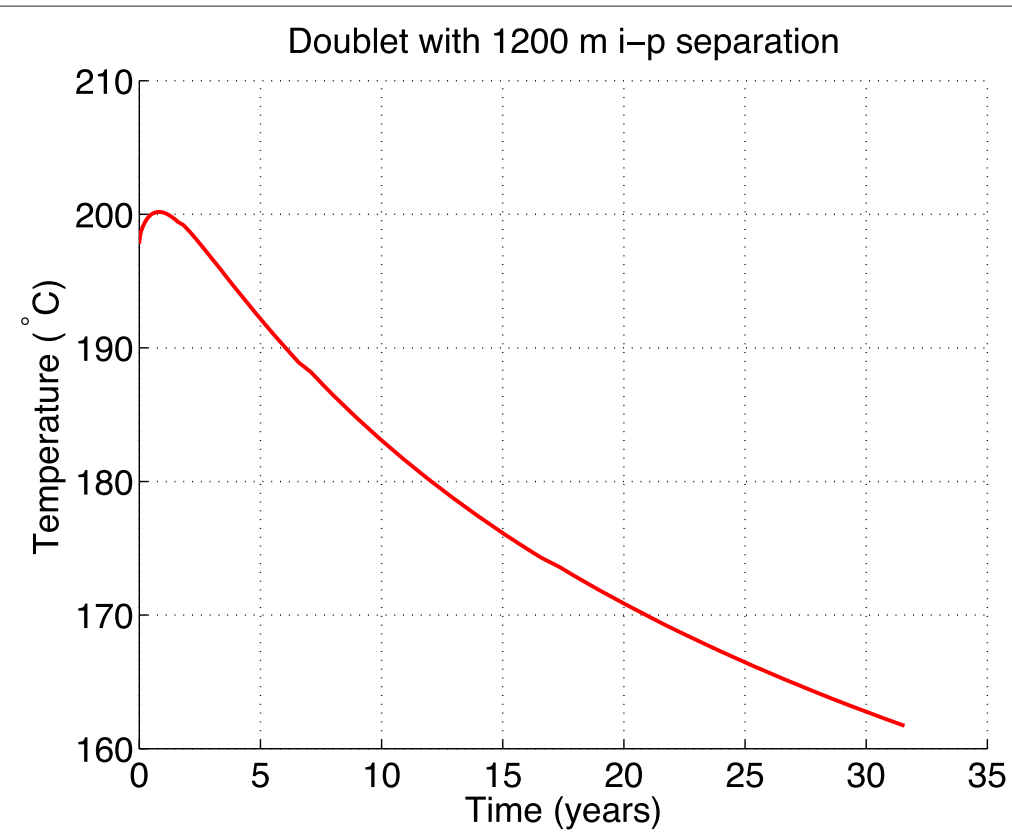

Fig. 4 Bottom-hole temperature at the producer at a flow rate of $50 \mathrm{~L} \mathrm{~s}^{-1}$

model parameters, namely, injector-producer (i-p) separation and flow rates are varied systematically and their effects are observed.

On the surface, wells are drilled next to or deviated from each other whereas their bottom-holes in the deeper sections of the reservoir are placed a few hundred meters apart (Genter et al. 2009). Economic feasibility of an EGS reservoir cannot be ensured unless the production flow rates are sufficiently high enough (Tester et al. 2006). Owing to lower energy density of water compared to hydrocarbons, a geothermal well needs to

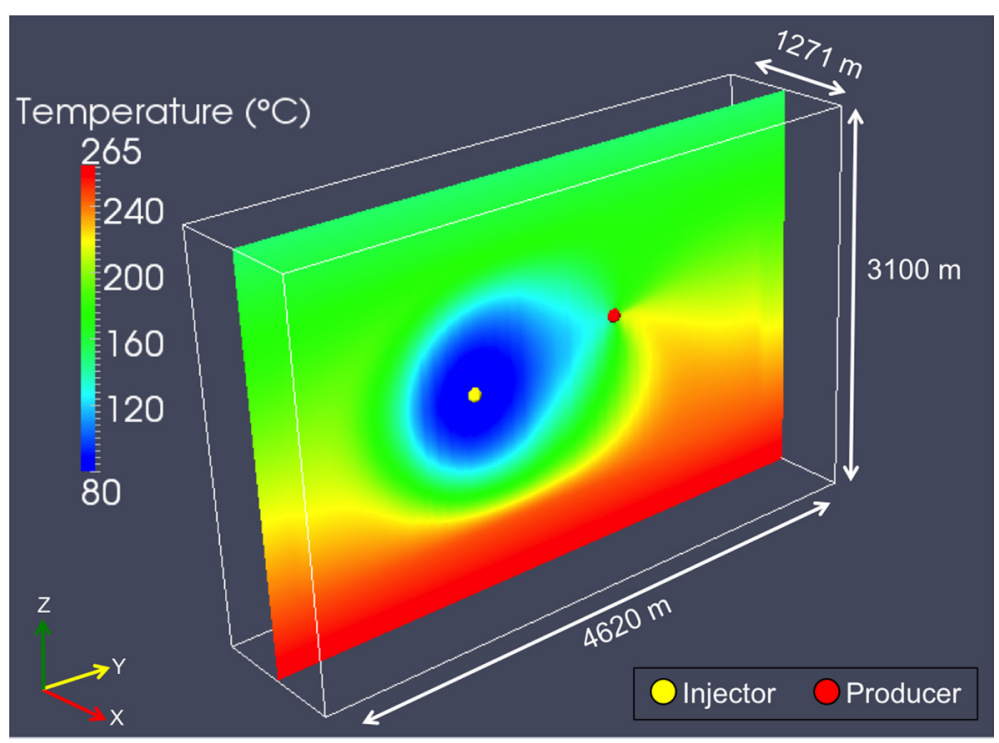

Fig. 5 Cross section showing temperature distribution after 31 years in high-permeability heat exchange area corresponding to water circulation at $50 \mathrm{~L} \mathrm{~s}^{-1}$ 
produce hot water at very high flow rates so as to become comparable with an oil well in terms of energy content. Higher flow rates are only possible if the reservoir transmissivity is high, where transmissivity $\boldsymbol{T}$ is defined as the product of hydraulic conductivity $K$ and reservoir thickness $d(\boldsymbol{T}=K \cdot d)$. Increasing transmissivities will allow higher flow rates (Tester et al. 2006). But very high flow rates can also be counterproductive as they may cause thermal short-circuiting between wells, thereby not allowing sufficient residence time for the re-injected cold water to be heated up again by the rock at depth.

\section{Doublet}

For the doublet optimization, nine models are created with different i-p separations from 400 to $2000 \mathrm{~m}$ with a step increase of $200 \mathrm{~m}$ while keeping other properties the same. Each model is run at three different flow rates (constant over time) of 50,100, and $150 \mathrm{~L} \mathrm{~s}^{-1}$. The following optimization steps are carried out for all the models.

Thermal power $P_{t}(\mathrm{~W})$ is evaluated using the bottom-hole temperatures $T\left({ }^{\circ} \mathrm{C}\right)$ from the producers as:

$$
P_{t}=\rho_{w} \cdot c_{p} \cdot \Delta T \cdot Q
$$

where $\rho_{w}$ is water density $\left(862 \mathrm{~kg} \mathrm{~m}^{-3}\right), c_{p}$ is specific heat capacity (constant value of $4510 \mathrm{~J} \mathrm{~kg}^{-1} \mathrm{~K}^{-1}$ for calculations), $\Delta T=T-80$ is the temperature difference between the produced and injected water $(K)$, and $Q$ is the production flow rate $\left(\mathrm{m}^{3} \mathrm{~s}^{-1}\right)$. It is assumed that there is no temperature drop while the produced hot water is ascending through the cooler sections of the crust. For a binary plant working on organic rankine cycle (ORC) with bottom-hole temperature-dependent thermal efficiency $\eta_{t}$ (Beardsmore et al. 2010), and accounting for the parasitic installation consumption $P_{i c}(\mathrm{~W})$ by the pumps, electric power $P_{e}(\mathrm{~W})$ is evaluated as:

$$
\begin{aligned}
P_{e} & =\left(P_{t} \cdot \eta_{t}\right)-P_{i c} \\
\eta_{t} & =0.00052 \cdot T+0.032 \\
P_{i c} & =\left(2 \cdot \rho_{w} \cdot g \cdot Q \cdot \Delta H\right) / \eta_{p}
\end{aligned}
$$

where $\Delta H$ is the head difference $(\mathrm{m})$ between wells and $\eta_{p}$ is the pump efficiency. Though pump efficiency is flow rate dependent and varies between 70-90\%, an optimal value of $90 \%$ is used for the calculations. Electric energy produced over 31 years is evaluated by integrating electric power over time, and a maxima is found among all the models.

Doublets with larger i-p separations have higher surface area for the heat exchangers, thereby producing more energy. On the other hand, doublets with high flow rates produce higher electric energy initially but the energy production gradually decreases with time owing to thermal drawdown and higher installation consumption by pumps. A balance needs to be achieved here, and a doublet with an i-p separation of $2000 \mathrm{~m}$ operating at an injection flow rate of $100 \mathrm{~L} \mathrm{~s}^{-1}$ yields the maximum electric energy over 31 years hence proving to be the optimal doublet design (Figs. 6 and 7). Considering that the wells are drilled from the same well-pad, $2000 \mathrm{~m}$ is taken as the maximum i-p separation which is practically viable. Keeping the i-p separation fixed as $2000 \mathrm{~m}, 11$ models are run with different flow rates from 50 to $150 \mathrm{~L} \mathrm{~s}^{-1}$ with a step increase of $10 \mathrm{~L} \mathrm{~s}^{-1}$. The results from these models also corroborate the previous finding. 


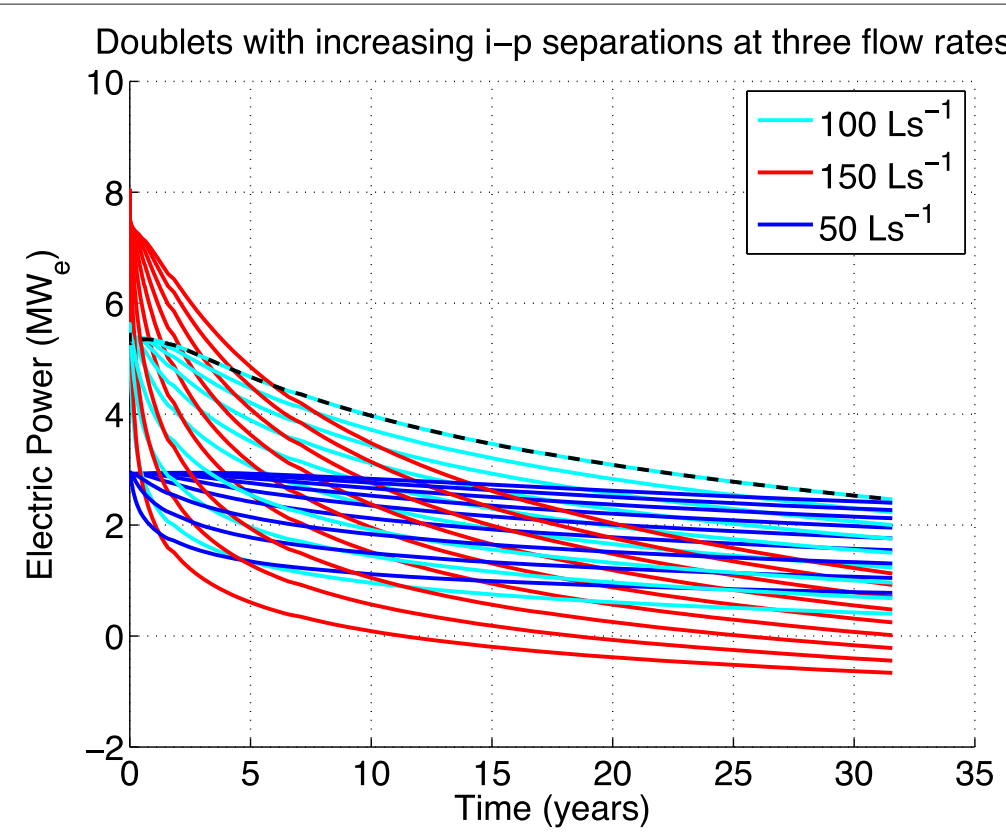

Fig. 6 Electric power $\left(\mathrm{MW}_{e}\right)$ for doublets. For increasing i-p separations from 400 to $2000 \mathrm{~m}$ at flow rates of 50,100 , and $150 \mathrm{~L} \mathrm{~s}^{-1}$. The dashed black line represents the optimized doublet design with the highest average electric power (see Table 4)

\section{Fractured zone permeability}

A permeability of $10^{-11} \mathrm{~m}^{2}$ is used for the fractured zone in the models after several trials. Stimulation increases the permeability of Soultz granite from $10^{-17}$ to $10^{-15} \mathrm{~m}^{2}$, and the main fracture has a permeability of $10^{-13} \mathrm{~m}^{2}$ (Vogt et al. 2012). With an i-p separation of $2000 \mathrm{~m}$ and a production flow rate of $100 \mathrm{~L} \mathrm{~s}^{-1}$, four models are run where

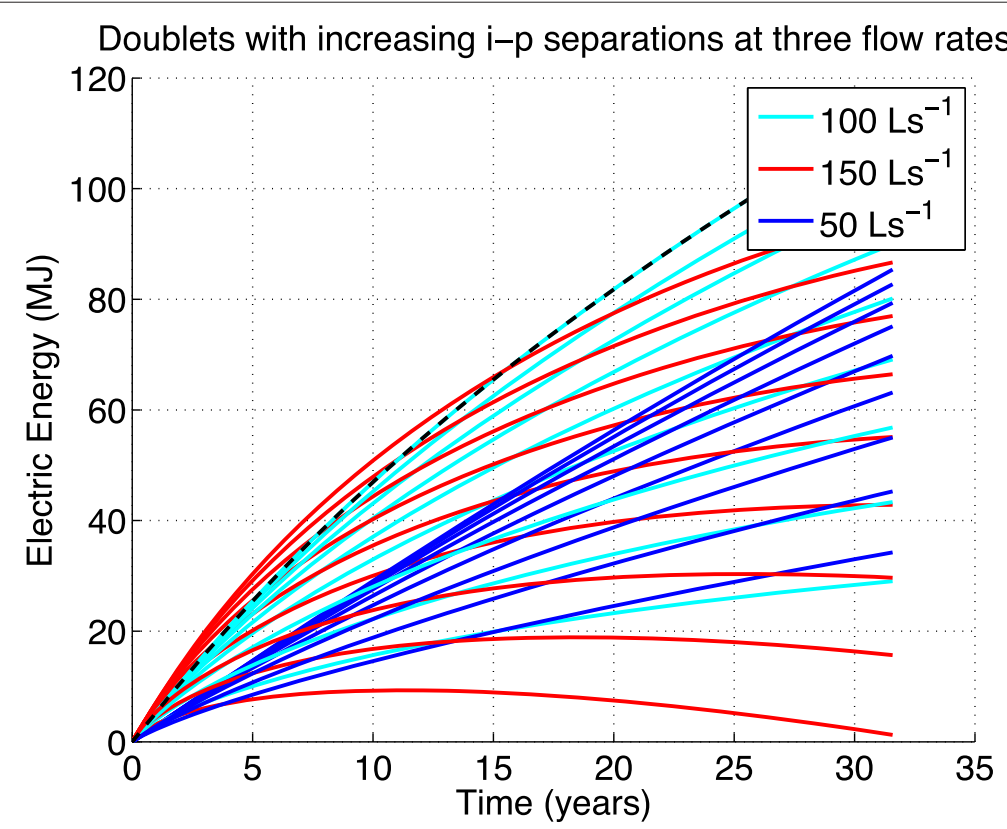

Fig. 7 Electric energy (MJ) for doublets. For increasing i-p separations from 400 to $2000 \mathrm{~m}$ at flow rates of 50, 100 , and $150 \mathrm{~L} \mathrm{~s}^{-1}$. The dashed black line represents the optimized doublet design with the highest electricity production (see Table 4) 
fractured zone permeabilities vary between $10^{-10}$ and $10^{-13} \mathrm{~m}^{2}$ with decreasing order of magnitude. Reservoir impedance $i$ (Eq.12) of an EGS should stay within the threshold of $100 \mathrm{kPa} \mathrm{s} \mathrm{L}^{-1}$ to ensure its commercial feasibility (Clauser 2006). Defined as the pressure drop between injectors and producers divided by the production flow rate, it can be understood as the pressure difference necessary to circulate a certain fluid volume (Kolditz and Clauser 1998).

$$
i=\frac{\bar{p}_{\text {injector }}-\bar{p}_{\text {producer }}}{Q}
$$

where $\bar{p}=\rho_{f} \cdot g \cdot \bar{h}$ is the average pressure $(\mathrm{Pa})$ in the injector or the producer. The reservoir impedance values for the four models are given in Table 3. On comparing the values, the fractured zone permeabilities of $10^{-10}$ and $10^{-11} \mathrm{~m}^{2}$ give a reservoir impedance below $100 \mathrm{kPa} \mathrm{s} \mathrm{L}{ }^{-1}$. A very high permeability of $10^{-10} \mathrm{~m}^{2}$ will yield more heat but following Freeze and Cherry (1979), a permeability of $10^{-11} \mathrm{~m}^{2}$ is assigned to the fractured zone.

\section{Surrounding zone width}

The extent of fluid circulation in an EGS reservoir differs from site to site around the world and depends on the region's tectonic history and stress regimes that govern the geometry, distribution, and apertures of existing fractures. For example, the natural fracture network extends over thousands of meters in the reservoir at Soultz-sous-Forêts (Vogt et al. 2012). To see how much volume is being accessed by the circulating water, we tested different widths of the surrounding zone (zone 4), ranging from 31 to $311 \mathrm{~m}$. A marginal increase in energy production is observed as the heat-transfer volumes (portion of reservoir volume accessible by the circulating fluids (Brown et al. 1999)) increase with surrounding zone width. In other words, a doublet can extract more heat when the width is $311 \mathrm{~m}$ rather than $31 \mathrm{~m}$. This increase in heat-transfer volume is most prominent at the depth of injection and becomes more or less the same for the regions above and below the injection point irrespective of the width.

\section{Triplet and reversed-triplet}

It is a common practice in EGS projects, for example, at Soultz-sous-Forêts and Rosemanowes, to have more than one well producing hot water on both sides of the central well re-injecting the used water back into the subsurface (Tester et al. 2006). Though requiring a higher initial investment, a triplet has a much larger heat-exchange area and produces more thermal energy from the reservoir compared to a doublet.

To accommodate a second producer, the starting model from subsection "Model geometry and properties" is extended along the direction of maximum compressive stress $\sigma_{1}$ with an i-p separation of $2000 \mathrm{~m}$ while keeping the thermal and hydraulic properties the same. Eleven models are run with different injection flow rates from 100 to $200 \mathrm{~L} \mathrm{~s}^{-1}$

Table 3 Reservoir impedance at different fractured zone permeabilities and a flow rate of $100 \mathrm{~L} \mathrm{~s}^{-1}$

\begin{tabular}{ll}
\hline Permeability $\left(\mathrm{m}^{2}\right)$ & Reservoir impedance $\left(\mathrm{kPa} \mathrm{s} \mathrm{L}^{-1}\right)$ \\
\hline $10^{-10}$ & 2.77 \\
$10^{-11}$ & 47.62 \\
$10^{-12}$ & 431.75 \\
$10^{-13}$ & 2080.65 \\
\hline
\end{tabular}


with a step increase of $10 \mathrm{~L} \mathrm{~s}^{-1}$. For each model, there are two wells producing hot water at half the injection flow rate. Similar to subsection "Doublet", optimization steps are performed to evaluate the electric energy produced. A triplet with an i-p separation of $2000 \mathrm{~m}$ operating at an injection flow rate of $150 \mathrm{~L} \mathrm{~s}^{-1}$ yields the maximum electric energy over 31 years hence proving to be the optimal triplet design.

A reversed-triplet is obtained by having one producer at the center and two injectors on the sides. With an i-p separation of $2000 \mathrm{~m}, 11$ models are run with different injection flow rates from 50 to $100 \mathrm{~L} \mathrm{~s}^{-1}$ with a step increase of $5 \mathrm{~L} \mathrm{~s}^{-1}$. For each model, there is one well producing hot water at twice the injection flow rate. Following the optimization steps, a reversed-triplet with an i-p separation of $2000 \mathrm{~m}$ operating at an injection flow rate of $90 \mathrm{~L} \mathrm{~s}^{-1}$ yields the maximum electric energy over 31 years hence proving to be the optimal reversed-triplet design. The three designs are compared in Table 4.

\section{Modular layouts}

Engineered geothermal systems are modular and scalable from $10^{0}$ to $10^{2} \mathrm{MW}_{e}$ as multiple instances of doublet/triplet/reversed-triplet may be implemented in the reservoir, in principle. Directional drilling techniques allow multiple wells being drilled from the same well-pad thus minimizing the land footprint. Heat-to-power conversion plant, cooling towers, and auxiliary buildings are relatively compact, and the surrounding area can support farming, grazing, or fisheries (Clauser 2006; Tester et al. 2006). To achieve higher power density $\left(\mathrm{MW}_{e} \mathrm{~km}^{-2}\right)$, this study proposes layouts where three vertical fractured zones (zone 5) are engineered next to each other. To this end, the starting model from subsection "Model geometry and properties" is extended to accommodate three fractured zones (zone 5) encompassed by one common surrounding zone (zone 4) in the reservoir. Each fractured zone has two doublets located along the $y$-direction.

With injectors on the outside, the producers are located in the middle at a separation of $250 \mathrm{~m}$. We consider three such fractured zones aligned parallel to each other along the $x$-direction and run four models with an injection flow rate of $100 \mathrm{~L} \mathrm{~s}^{-1}$ for a series of separation and width values. As separation or width increases, the overlap between the heat-transfer volumes (subsection "Surrounding zone width") of adjacent doublets decreases. As a result, the electric energy produced increases marginally but this comes at the expense of an increased well-field area. For obtaining simultaneously minimum wellfield area and maximum power output, an optimal layout (i.e., the highest power density in $\mathrm{MW}_{e} \mathrm{~km}^{-2}$ ) is obtained by implementing six doublets with separations and widths of $250 \mathrm{~m}$. Building on the same principle as before, six triplets or six reversed-triplets can be implemented in the reservoir. Although the simulations were performed for three vertical fractured zones (or six instances of doublets/triplets/reversed-triplets), these layouts can

Table 4 Potential of three optimized EGS designs with an i-p separation of 2000 m

\begin{tabular}{|c|c|c|c|}
\hline Parameter & Doublet & Triplet & Reversed-triplet \\
\hline Injection flow rate $\left(L \mathrm{~s}^{-1}\right)$ & 100 & 150 & 90 \\
\hline Average thermal power $\left(\mathrm{MW}_{t}\right)$ & 38.0 & 57.7 & 68.3 \\
\hline Average electric power $\left(\mathrm{MW}_{e}\right)$ & 3.6 & 5.3 & 6.3 \\
\hline Surface area required ${ }^{\mathrm{a}}\left(\mathrm{km}^{2}\right)$ & 0.7 & 1.3 & 1.3 \\
\hline Electric energy produced in 31 years (TJ) & 3584 & 5260 & 6251 \\
\hline
\end{tabular}

aprojection of the subsurface heat-exchange area on the surface. The actual land footprint is much less 
be extrapolated or factorized to better suit a specific EGS project. The potential of these modular layouts is compared in Table 5 .

\section{EGS potential in Germany}

Germany has witnessed a boom lately in terms of the installed capacity of geothermal heat pumps for space heating, but the development of EGS for electricity generation is still in its infancy. According to BMWi 2012, 80 deep geothermal projects had been established by the end of the year 2006, but only five projects at Insheim (4.8 $\left.\mathrm{MW}_{e}\right)$ (Breede et al. 2013), Unterhaching $\left(3.4 \mathrm{MW}_{e}\right)$ (BINE 2009), Landau (3 $\mathrm{MW}_{e}$ ) (BINE 2007) ${ }^{1}$, NeustadtGlewe (0.23 $\mathrm{MW}_{e}$ ) (Schellschmidt et al. 2010), and Bruchsal (0.55 MW $)$ (BMWi 2012; Münch et al. 2010) are producing electricity as of today. Renewables accounted for $20 \%$ of the gross power production in Germany for year 2011 (612 TWh), while the rest was produced by nuclear- or fossil-fuelled plants (BDEW 2011). In the wake of the recent Fukushima Daiichi nuclear disaster in Japan, Germany decided to phase out nuclear power plants by the year 2022. To compensate for this reduced electricity production and to cut down greenhouse gas emissions in compliance with the Kyoto Protocol, Germany has to rely heavily on renewables like geothermal energy. Ratification of the ErneuerbareEnergien-Gesetz (EEG) Act in the year 2000 (Purkus and Barth 2011) and increment of EEG feed-in tariffs for geothermal power in the year 2009 (DeutscherBundestag 2008) show growing political and public support towards geothermal electricity production. To highlight the potential contribution of EGS towards future energy market in Germany, we performed an in-depth land-use-based study here.

\section{Available land area}

Jung et al. (2002) propose three potential crystalline areas around Germany for geothermal power generation in the depth range of 3-7 km using EGS technology (Fig. 8). These sources are the Central and Southern German crystalline area, the Upper Rhine Valley crystalline area, and the Rotliegend volcanics in the Northern German basin where the average geothermal gradient is around $30 \mathrm{~K} \mathrm{~km}^{-1}$ (BGR 2009). All these regions correspond to a minimum temperature of $100-130^{\circ} \mathrm{C}$ at a depth of $3 \mathrm{~km}$. A temperature of $150{ }^{\circ} \mathrm{C}$ has been defined at a depth of $4 \mathrm{~km}$ in the models, which is in agreement with the actual temperature values.

Considering this crystalline area map (Fig. 8) as the base, land area of Germany is evaluated as $350,592 \mathrm{~km}^{2}$ using longitudinal and latitudinal distances. A marginal $0.6 \%$ increase from the actual land area (DESTATIS 2014) highlights the high accuracy and

Table 5 Potential of three optimized EGS layouts

\begin{tabular}{llll}
\hline Parameter & 6 Doublets & 6 Triplets & 6 Reversed-triplets \\
\hline Average electric power $\left(\mathrm{MW}_{e}\right)$ & 20.1 & 31.1 & 35.3 \\
Power density $\left(\mathrm{MW}_{e} \mathrm{~km}^{-2}\right.$ ) & 5.7 & 4.7 & 5.3 \\
Systems possible in 89,000 $\mathrm{km}^{2}$ & 25,360 & 13,450 & 13,450 \\
Electric energy delivered in 1 year by all systems (TWh) & 4466 & 3660 & 4155 \\
$\begin{array}{l}\text { Electric energy delivered at any time by all systems for a } \\
\text { resource base of 500 years (TWh) }\end{array}$ & 277 & 227 & 258 \\
$\begin{array}{l}\text { Available heat (EJ) } \\
\text { Theoretical potential (GW })\end{array}$ & 9080 & 9080 & 9080 \\
Extractable part of theoretical potential $\left(\mathrm{GW}_{e}\right)$ & 928 & 928 & 928 \\
\hline
\end{tabular}




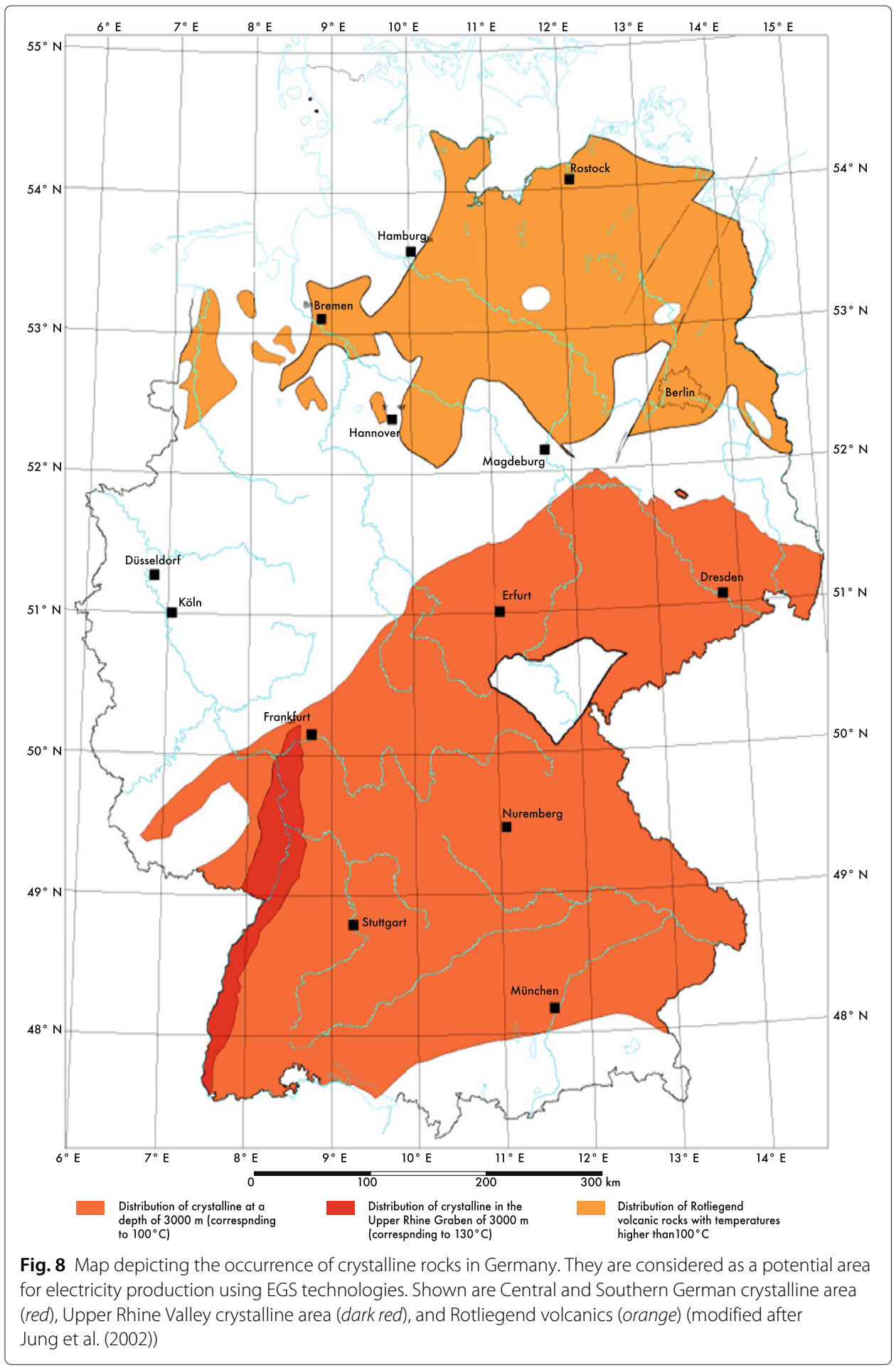

reliability of the calculation. Next, the area covered by the crystalline rocks acting as the potential source is evaluated. Owing to competing land uses, only a portion of this crystalline area can be used for engineering EGS reservoirs after excluding area covered by the following: 
- Protected areas (nature parks, national parks, and biosphere reserves) by comparing available maps and datasets (BfN 2011).

- Seismically hazardous zones associated with macro-seismic intensities of VI (corresponding to light potential damage) and above (Grünthal 2004).

- Infrastructure and transport (6.9 and $5.0 \%$ of the leftover area, respectively) (DESTATIS 2014).

This leaves behind the crystalline area with EGS potential as $89,000 \mathrm{~km}^{2}$ (Fig. 9). This corresponds to around one-fourth of Germany's land area or $44 \%$ of the actual crystalline area. Theoretically, there is enough potential crystalline area to support 25,360 EGS plants with six doublets or 13,450 EGS plants with six triplets/reversed-triplets. How this translates into terms of produced energy and potential electric power is discussed next.

\section{Available heat and potential}

The heat $H(J)$ available in 1-km-thick basement (starting at a depth of $5 \mathrm{~km}$ ) below this potential area of $89,000 \mathrm{~km}^{2}$ is evaluated as $9078 \mathrm{EJ}$ using the relation:

$$
H=\rho_{r} \cdot c_{p} \cdot V \cdot\left(T_{x}-T_{r}\right)
$$

where $\rho_{r}$ is the density of granite ( $2550 \mathrm{~kg} \mathrm{~m}^{-3}$ (Beardsmore et al. 2010)), $c_{p}$ is the specific heat capacity of granite (1000 $\mathrm{J} \mathrm{kg}^{-1} \mathrm{~K}^{-1}$ (Beardsmore et al. 2010)), $V$ is the basement volume $\left(89,000 \mathrm{~km}^{3}\right), T_{x}$ is the average temperature of the basement volume $\left(200^{\circ} \mathrm{C}\right.$ from our models), and $T_{r}$ is the temperature to which the crust can be reduced $\left(160^{\circ} \mathrm{C}\right.$ from bottom-hole temperatures).

For an EGS plant's operational life of 31 years, the theoretical potential electric power $P_{p}\left(\mathrm{~W}_{e}\right)$ (Beardsmore et al. 2010) is evaluated as $928 \mathrm{GW}_{e}$ using the relation:

$$
P_{p}=\left(H \cdot \eta_{t}\right) /(31 \cdot 365 \cdot 86,400)
$$

with $\eta_{t}$ from Eq. 10. According to our simulations, 13,450 EGS plants with six reversedtriplets at an average electric power of $35.3 \mathrm{MW}_{e}$ (see Table 5) can collectively yield an extractable potential power of $474 \mathrm{GW}_{e}$. This is around $51 \%$ of the theoretical potential power $\left(928 \mathrm{GW}_{e}\right)$ as the areas which limit the possibility of EGS have been excluded in

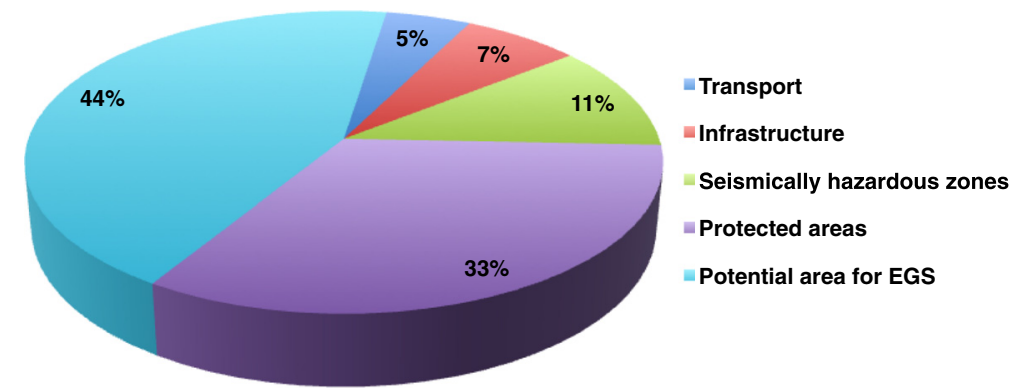

Fig. 9 Competing land use types in the crystalline area of Germany. Area with EGS potential is around $89,000 \mathrm{~km}^{2}$ 
this calculation. In a scenario where these 13,450 plants exist and are running all yearround at full capacity, they can supply $4155 \mathrm{TWh}$ of electric energy in 1 year. This would be sevenfold the electric energy produced in Germany in the year 2011.

Fox et al. (2013) have classified the EGS reservoirs as renewable and capable of producing energy sustainably. Based on their calculations, reservoirs can be recycled postproduction as a significant amount of their original thermal energy will recover over time scales which are two-to-four times the production time. Covering a resource base for 500 years (a rather conservative estimate) and an operation time of 31 years, these 13,450 EGS plants can deliver $258 \mathrm{TWh}$ of electric energy. To summarize, EGS has the potential to deliver $42 \%$ of German power production (612 TWh in year 2011) at any given time. Table 5 compares the potential of three optimized EGS layouts.

\section{Comparison with other renewables}

The number of possible EGS installations in Germany may sound unrealistic at first, but it is not unreasonable when compared to the existing number of wind turbines and solar PV systems in the country. According to DEWI (DEWI 2012), Germany had 22,297 wind turbines by the end of the year 2011 with an installed capacity of $29.07 \mathrm{GW}_{e}$. Considering a power density of 5-8 $\mathrm{MW}_{e}$ per $\mathrm{km}^{2}$ (Sesto and Casale 1998), this corresponds to anywhere between 3635 and $5815 \mathrm{~km}^{2}$ of land use. Solar power accounted for $12 \%$ of total electric energy delivered by renewables with its 1,090,000 PV installations by the end of the year 2011 (BDEW 2011; BSW 2012). For generating electricity by biomass (solid/liquid fuels, bio/sewage/landfill gas, and biogenic fraction of waste), $20,000 \mathrm{~km}^{2}$ of agricultural land was used in the same year (BMU 2009). The share of different renewables towards electricity production is compared in Table 6.

The share of renewable energies towards electricity generation will continue to rise as Germany aims to produce $80 \%$ of its electricity using renewables by the year 2050 (BDEW 2011). As mentioned before, a large number of deep geothermal projects are already under development. Wind energy is expected to grow both onshore and offshore, especially with the proposed installation of the $25 \mathrm{GW}_{e}$ offshore wind farm in the North Sea by the year 2030 (Morkel et al. 2007). According to BSW forecasts, the share of solar PV in German gross power production will rise from $4 \%$ in 2012 to $10 \%$ in 2020 (BSW 2012). Land area under biomass is also projected to climb to $25,000-40,000 \mathrm{~km}^{2}$ by the year 2020 (BMU 2009), thus doubling its share towards energy supply.

Irrespective of the current installed capacity of only $8 \mathrm{MW}_{e}$, geothermal energy offers an attractive option for producing green energy. EGS plants are independent of seasonal variations and are capable of delivering base-load electricity unlike wind and solar power. Compared to biomass which has to compete with food crops for using the land area, EGS plants have a limited surface footprint and they provide much higher power density.

Table 6 Contribution of renewables towards electricity production (BDEW 2011; BSW 2012; DEWI 2012

\begin{tabular}{llllc}
\hline Parameter & Geothermal & Wind & Solar PV & Biomass \\
\hline Existing systems (2011) & 4 & 22,297 & $1,090,000$ & - \\
Installed capacity (2011) $\left(\mathrm{GW}_{e}\right)$ & 0.008 & 29.07 & 24.80 & - \\
Installed capacity (2010) $\left(\mathrm{GW}_{e}\right)$ & 0.008 & 27.21 & 17.48 & 6.38 \\
Electric energy delivered (2010) (GWh) & 28 & 37,793 & 11,683 & 30,392 \\
Share in renewable power (2011) (\%) & 0.02 & 39.18 & 12 & 28 \\
\hline
\end{tabular}




\section{Conclusions}

Heat extraction from EGS reservoirs is a challenging task owing to limited subsurface knowledge and inaccessibility to rock volume (Pettitt et al. 2011). As the projects extend beyond prior experience, numerical modeling assists in studying the long-term response of EGS reservoirs towards stimulation. We are aware that currently realized flow rates in existing EGS sites (Baria et al. 1999; Breesee 2015) are insufficient to allow for a significant contribution from geothermal energy towards Germany's energy supply. We also acknowledge that systems such as those which we modeled currently cannot be engineered in the basement rock yet. However, given that the required technological improvements (Bertani 2009; Tester et al. 2006) will become available in time, technically feasible flow rates may be expected to increase in the future. Hence, our results are based on the assumption that flow rates of up to $150 \mathrm{~L} \mathrm{~s}^{-1}$ will become possible by progress in future drilling and stimulation technology. Induced seismicity inevitably accompanies hydraulic fracturing during the installation and operation of EGS. However, the probability of events of a given magnitude can be estimated (for example, see Shapiro et al. (2007)) and research is ongoing to minimize associated magnitudes by controlling the mode and magnitude of injection flow rates and pressure (Tester et al. 2006; Zang et al. 2013). Moreover, other stimulation methods such as thermal, chemical, or combined approaches are also under development. While this is a critical point for public acceptance of EGS technology, this topic is beyond the scope of our study.

Feasibility studies have shown that engineered geothermal systems can be deployed after predictably engineering the geothermal reservoirs for fractures. EGS plants have the capacity to exploit the thermal heat stored within the Earth's crust irrespective of the reservoir rock permeability or availability of geothermal fluids. Assuming that the engineering of single "coin-shaped" fractures in EGS reservoirs will become feasible technologically in the future, we simulate the large-scale response of reservoir rock towards fluid injections. By systematically varying flow rates and well separations in the subsurface, the task of optimizing the system for producing the highest possible electric energy has been accomplished here, and three different EGS layouts are proposed for achieving efficient heat extraction from the reservoirs.

Consisting of three vertical fracture zones engineered in the subsurface, each of these optimized layouts implement six instances of doublets/triplets/reversed-triplets with an injector-producer separation of $2000 \mathrm{~m}$. The producers of the same fractured zone are at a separation and width of $250 \mathrm{~m}$. Composed of six doublets, the first EGS layout when operated at a constant production flow rate of $100 \mathrm{~L} \mathrm{~s}^{-1}$ for 31 years yields an average electric power of $20.1 \mathrm{MW}_{e}$. The second layout comprises six triplets and supplies an average electric power of $31.1 \mathrm{MW}_{e}$ when operated at a constant production flow rate of $75 \mathrm{~L} \mathrm{~s}^{-1}$. The third layout with six reversed-triplets is obtained by reversing the well polarities in the second layout. This optimized layout delivers an average electric power of $35.3 \mathrm{MW}_{e}$ when operated for 31 years at a production flow rate of $180 \mathrm{~L} \mathrm{~s}^{-1}$. These layouts can be conveniently extrapolated or factorized to better suit the electric power required by a specific EGS project.

Furthermore, we evaluated the potential area for EGS plants in Germany in a comprehensive study considering available land area and competing land uses. Basing the calculation on the crystalline regions in the country and excluding the land area covered by protected areas, seismically hazardous zones, infrastructure, and transport, an area of 
$89,000 \mathrm{~km}^{2}$ is identified for EGS potential. This is sufficient for supporting 13,450 EGS plants (layout with six reversed-triplets) in the country corresponding to a maximum electric power capacity of $474 \mathrm{GW}_{e}$. In other words, EGS has the potential to deliver $4155 \mathrm{TWh}$ of electric energy in 1 year which would be sevenfold the German power production for the year 2011. Note that the geothermal potential is not derived from theoretical principles concerning the heat content of the rock, but by simulating the actual extracted heat from an engineered geothermal system, yielding a more realistic estimation of the potential.

Considering the rampant utilization of natural resources by humans and the increasing climate change, bold steps need to be taken on a unprecedented scale to avoid an imminent environmental disaster. A nationwide effort is required for restructuring the German energy market while ensuring its cost-effectiveness. Geothermal energy along with all other renewables need to be developed further by making them more efficient while assessing and mitigating their environmental impacts. Expansion of transmission grids is inevitable to connect the proposed wind farms in the North Sea to southern industrialized centers by adopting new transmission technologies like high-voltage direct current (HVDC) (BMU 2011). Social acceptance will be of paramount importance and thus awareness needs to be created among the general public about energy-saving measures and the environmental benefits of switching to low-carbon alternative energies. EGS plants provide non-intermittent power, have a minor surface footprint, and cause lowto-zero carbon emissions. To conclude, renewables like geothermal energy including its engineered geothermal systems will play a vital role in building a greener tomorrow.

\section{Endnote}

${ }^{1}$ Production in Landau is stalled until the pending claims regarding the triggering of induced seismicity have been settled.

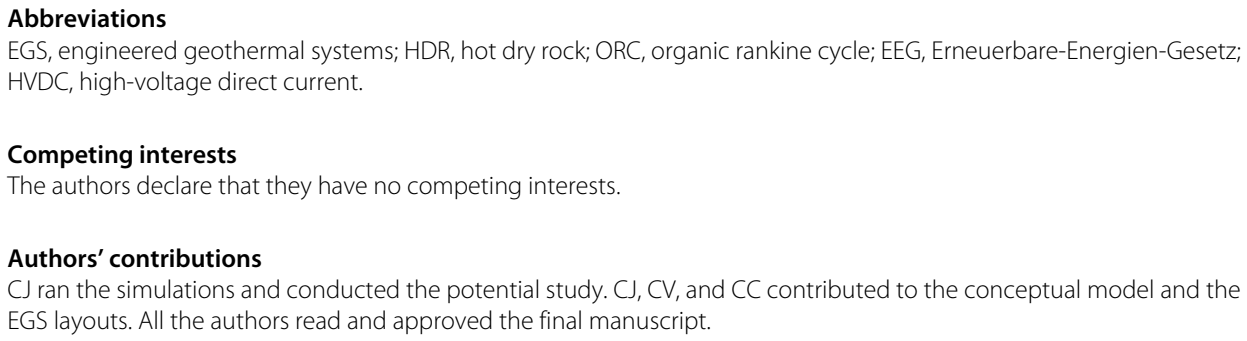


Beardsmore GR, Rybach L, Blackwell D, Baron C (2010) A protocol for estimating and mapping global EGS potential. In: Proceedings of the Geothermal Resources Council Annual Meeting, Sacramento, CA, USA

Bertani R (2009) Long term projection of geothermal electricity development in the world. In: Proceedings of the GeoTHERM Conference, Offenburg, Germany

BfN (2011) Protected Areas. Bundesamt für Naturschutz (BfN), Bonn. http://bit.ly/N7uoQt (Accessed 20 April 2015)

BGR (2009) Energy Resources 2009: reserves, resources, availability — crude oil, natural gas, coal, nuclear fuels, Geothermal Energy. Bundesanstalt für Geowissenschaften und Rohstoffe (BGR), Hannover

BINE (2007) Geothermische Stromerzeugung in Landau. Bundesministerium für Wirtschaft und Technologie, Berlin

BINE (2009) Geothermal electricity generation combined with a heating network. Bundesministerium für Wirtschaft und Technologie, Berlin

BMU (2009) National Biomass Action Plan for Germany. Bundesministeriums für Umwelt, Naturschutz und Reaktorsicherheit (BMU), Berlin and Bundesministerium für Ernährung, Landwirtschaft und Verbraucherschutz (BMELV), Bonn

BMU (2011) Renewable energy sources in figures—National and International Development. Bundesministeriums für Umwelt, Naturschutz und Reaktorsicherheit (BMU), Berlin

BMWi (2012) Research for an environmentally sound, reliable, and affordable energy supply —6th Energy Research Programme of the Federal Government. Bundesministerium für Wirtschaft und Technologie (BMWi), Berlin

Boussinesq J (1903) Théorie analytique de la chaleur. Gauthier-Villars, Paris

Breede K, Dzebisashvili K, Liu X, Falcone G (2013) A systematic review of enhanced (or engineered) geothermal systems: past, present and future. Geothermal Energy 1(1):4

Breesee JC (ed) (2015) The Soultz hot dry rock project. Gordon and Breach, Philadelphia

Brown DW, Duchane DV (1999) Scientific progress on the Fenton Hill HDR project since 1983. Geothermics 28(4-5):591-601

Brown D, DuTeaux R, Kruger P, Swanson D, Yamaguchi T (1999) Fluid circulation and heat extraction from engineered geothermal reservoirs. Geothermics 28(4-5):553-572

BSW (2012) Statistic data on the German solar power (photovoltaic) industry. Bundesverband Solarwirtschaft (BSW), Berlin

Clauser C (ed) (2003) Numerical simulation of reactive flow in hot aquifers: SHEMAT and processing SHEMAT. Springer Verlag, Heidelberg-Berlin

Clauser C (2006) Geothermal energy. In: Heinloth K (ed). Landolt-Börnstein, Group VIII: Advanced Material and Technologies, Vol. 3: Energy Technologies, Subvol. C: Renewable Energies. Springer Verlag, Heidelberg-Berlin. pp 493-604

DESTATIS (2014) Land use—use of area. Statistisches Bundesamt (DESTATIS), Wiesbaden. http://bit.ly/1 JZcFsO (accessed on: 20.04.2015)

DeutscherBundestag (2008) Gesetz zur Neuregelung des Rechts der Erneuerbaren Energien im Strombereich und zur Änderung damit zusammenhängender Vorschriften vom 25 Oktober 2008. Bundesgesetzblatt 2008(49):2074-2100

DEWI (2012) Status der Windenergienutzung in Deutschland - Stand 31.12.2011. Deutsches Windenergie-Institut (DEWI), Wilhelmshaven

Economides MJ, Nolte KG (eds) (2003) Reservoir stimulation, 3rd ed. John Wiley, Hoboken, New Jersey

Freeze AR, Cherry JA (1979) Groundwater. Prentice Hall, New Jersey

Fox DB, Stutter D, Beckers KF, Lukawski MZ, Koch DL, Anderson BJ, Tester JW (2013) Sustainable heat farming: modeling extraction and recovery in discretely fractured geothermal reservoirs. Geothermics 46(0):42-54

Genter A, Fritsch D, Cuenot N, Baumgärtner J, Graff JJ (2009) Overview of the current activities of the European EGS Soultz project: from exploration to electricity production. In: Proceedings of the Thirty-Fourth Workshop on Geothermal Reservoir Engineering. Stanford, CA, USA

Gérard A, Genter A, Kohl T, Lutz P, Rose P, eds (2006) The deep EGS (enhanced geothermal system) project at Soultz-sous-Forêts, Alsace, France [Special issue]. Geothermics 35(5-6):473-714

Grünthal G (2004) Erdbeben und Erdbebengefährdung in Deutschland sowie im Europäischen Kontext. Geographie und Schule 151(26):14-23

Heidinger P (2010) Integral modeling and financial impact of the geothermal situation and power plant at Soultz-sous-Forêts. C R Geosci 342(7-8):626-635

Jung R, Röhling S, Ochmann N, Rogge S, Schellschmidt R, Schulz R, Thielemann T (2002) Abschätzung des Technischen Potenzials der Geothermischen Stromerzeugung und der Geothermischen Kraft-wärme-kopplung (KWK) in Deutschland - Bericht Für Das Büro Für Technikfolgenabschätzung Beim Deutschen Bundestag. Institut für Geowissenschaftliche Gemeinschaftsaufgaben, Hannover, Bundesanstalt für Geowissenschaften and Rohstoffe, Hannover, Institut für Energiewirtschaft und Rationelle Energieanwendung, Universität Stuttgart

Kohl T, Schmittbuhl J (2014) Characterization of deep geothermal systems. Geothermal Energy, London

Kohl T, Schmittbuhl J (2015) Characterization of deep geothermal systems. Geothermal Energy, London

Kolditz O, Clauser C (1998) Numerical simulation of flow and heat transfer in fractured crystalline rocks: application to the hot dry rock site in Rosemanowes (U.K.) Geothermics 27(1):1-23

Kühn M, Bartels J, Iffland J (2002) Predicting reservoir property trends under heat exploitation: interaction between flow, heat transfer, transport, and chemical reactions in a deep aquifer at Stralsund, Germany. Geothermics 31 (6):725-749

Morkel L, Toland A, Wende W, Köppel J (2007) The German offshore-foundation and the offshore wind energy test site. In: Proceedings of the 2nd Scientific Conference on the Use of Offshore Wind Energy, Berlin, Germany

Münch W, Kölbel T, Herzberger P, Schlagermann P, Hötzl H, Wolf L, Rettenmaier D, Steger H, Zorn R, Seib P, Möllmann G, Sauter M, Ghergut J, Ptak T (2010) The geothermal power plant Bruchsal. In: Proceedings of the World Geothermal Congress, Bali, Indonesia

NOAA (2012) Water density calculator. National Oceanic Atmospheric Administration (NOAA), Washington D.C. and Michigan State University, Michigan. http://bit.ly/fQzVL (accessed on: 20.04.2015)

Oberbeck A (1879) Über die Wärmeleitung der Flüssigkeiten bei Berücksichtigung der Strömungen infolge von Temperaturdifferenzen. Ann Phys 243(6):271-292 
Parker R (1999) The Rosemanowes HDR project 1983-1991. Geothermics 28(4-5):603-615

Pettitt W, Pierce M, Damjanac B, Hazzard J, Lorig L, Fairhurst C, Gil I, Sanchez M, Nagel N, Reyes-Montes J, Young RP (2011) Fracture network engineering for hydraulic fracturing. Leading Edge 30(8):844-853

Purkus A, Barth V (2011) Geothermal power production in future electricity markets—a scenario analysis for Germany. Energy Policy 39(1):349-357

Schellschmidt R, Sanner B, Pester S, Schulz R (2010) Geothermal energy use in Germany. In: Proceedings of the World Geothermal Congress, Bali, Indonesia

Sesto E, Casale C (1998) Exploitation of wind as an energy source to meet the world's electricity demand. J Wind Eng Ind Aerodyn. 74-76:375-387

Shapiro SA, Dinske C, Kummerow J (2007) Probability of a given-magnitude earthquake induced by a fluid injection. Geophys Res Lett 34(22):22314-1223145

Tester JW, Anderson BJ, Batchelor AS, Blackwell DD, DiPippo R, Drake EM, Garnish J, Livesay B, Moore MC, Nichols K, Petty S, Toksöz MN, Veatch RW, Baria R, Augustine C, Murphy E, Negraru P, Richards M (2006) The future of geothermal energy -impact of enhanced geothermal systems on the United States energy supply in the 21st century. Massachusetts Institute of Technology, Cambridge

Vogt C, Kosack C, Marquart G (2012) Stochastic inversion of the tracer experiment of the enhanced geothermal system demonstration reservoir in Soultz-sous-Forêts—revealing pathways and estimating permeability distribution. Geothermics 42:1-12

Zang A, Yoon JS, Stephansson O, Heidbach O (2013) Fatigue hydraulic fracturing by cyclic reservoir treatment enhances permeability and reduces induced seismicity. Geophys J Int 195(4-5):1282-1287

\section{Submit your manuscript to a SpringerOpen ${ }^{\odot}$ journal and benefit from:}

- Convenient online submission

- Rigorous peer review

- Immediate publication on acceptance

- Open access: articles freely available online

- High visibility within the field

- Retaining the copyright to your article

Submit your next manuscript at $\boldsymbol{\triangleright}$ springeropen.com 